\title{
Insulin Regulates the Paracellular Permeability of Cultured Intestinal Epithelial Cell Monolayers
}

James A. McRoberts, Richard Aranda, Nora Riley, and Hoon Kang

Division of Gastroenterology, Department of Medicine, Harbor-UCLA Medical Center

and the Inflammatory Bowel Disease Center, Torrance, California 90502

\begin{abstract}
The T84 human colonic epithelial cell line retains the ability to produce secretagogue-responsive monolayer cultures with high transepithelial resistance when grown and maintained on collagen-coated permeable supports in media supplemented with $5 \%$ newborn calf serum. The addition of highly purified insulin to the basolateral but not the apical membrane side of established monolayers caused the transepithelial resistance to decline more than eightfold over a 3-4-d period. By comparing the transepithelial flux of ${ }^{22} \mathrm{Na}$ with that of the extracellular space marker, $\left[{ }^{3} \mathbf{H}\right]$ mannitol, the decline in electrical resistance was shown to be due solely to an effect on tight junction-mediated paracellular permeability. The effect of insulin was dose dependent with a half-maximal effect at $3.9 \mathrm{ng} / \mathrm{ml}(\sim 0.7 \mathrm{nM})$ and fully reversible over a $10-d$ time course. Simultaneous addition of $2 \mu \mathrm{M}$ cycloheximide prevented the insulin-induced decline in resistance; in fact, this combination caused a signifcant increase in electrical resistance. There was no effect on the short-circuit current response of insulin-treated monolayers to secretagogues so long as media was changed daily. While no gross morphological changes were apparent, there did appear to be a subtle condensation of the perijunctional actin ring as visualized using rhodamine-labeled phalloidin. These results demonstrate that insulin modulates the permeability of the occluding junction in $\mathbf{T 8 4}$ cell monolayers through a receptor mediated process which probably involves changes in protein synthesis and cytoskeletal structure. Insulin was also shown to produce similar effects on two other intestinal epithelial cell lines. (J. Clin. Invest. 1990. 85:11271134.) cell lines • intercellular junctions • electrical conductivity $\bullet$ cytoskeleton $\bullet$ microfilaments
\end{abstract}

\section{Introduction}

The human colonic epithelial cell line, T84, was derived from a well-differentiated adenocarcinoma (1). When grown in serum-supplemented media on collagen-coated permeable supports, T84 cells produce a monolayer of columnar-shaped

Portions of this work were presented in abstract form at the 89th Annual Meeting of the American Gastroenterological Association in Washington, DC, May 1989 (1989. Gastroenterology. 96:A337).

Address reprint requests to Dr. McRoberts, Division of Gastroenterology, C-1 Trailer, Harbor-UCLA Medical Center, 1124 W. Carson St., Torrance, CA 90502.

Received for publication 28 July 1989 and in revised form 7 November 1989.

J. Clin. Invest.

(C) The American Society for Clinical Investigation, Inc.

$0021-9738 / 90 / 04 / 1127 / 08 \quad \$ 2.00$

Volume 85, April 1990, 1127-1134 cells which morphologically resemble fetal colon crypt epithelial cells (2). Monolayers typically display transepithelial resistances of $\sim 1,500 \Omega-\mathrm{cm}^{2}$, the development of which is associated with the formation of extensive tight junctional networks between adjacent cells (3). When such monolayers are mounted in voltage-clamped Ussing chambers, there is very little if any vectorial solute transport. Addition of a number of hormones or other effectors (secretagogues) induces an electrogenic chloride secretory response which is reflected by an increased positive short-circuit current $\left(I_{s c}\right)^{1}(4,5$, reviewed in reference 6). Since $\mathrm{Cl}^{-}$secretion is a property of the crypt epithelia of the intestine (7), these observations became the basis for establishing T84 cells as a cell culture model system with which to investigate secretory responses of the intestine.

All of these observations were made on T84 cell monolayers grown in serum supplemented media. T84 cells can also be grown in a serum-free defined media containing transferrin, insulin, selenium, ascorbic acid, epidermal growth factor, hydrocortisone, and triiodothyronine (1). T84 cells grown in defined media do not produce simple monolayer cultures, but instead tend to pile up and produce structures morphologically resembling the original tumor (1). In this laboratory we have begun to investigate the components of defined media with the objective of formulating a serum-free media which would support the production and maintenance of the differentiated properties of T84 cells. In the course of this investigation, we have found that one of the hormones routinely added to nearly all formulations of defined media, insulin, caused a pronounced decline in the transepithelial resistance without affecting the ability of the monolayers to respond to secretagogues.

Insulin in vivo mediates a diverse array of metabolic effects generally aimed at increasing the uptake, utilization and storage of nutrients (8). In vitro insulin is a strong mitogen for a number of different cell types and therefore is included in defined media formulations (9). The concentrations of insulin used in such media are usually superphysiologic $(1-15 \mu \mathrm{g} / \mathrm{ml})$ and commonly believed to exert their mitogenic effect through interaction with type I insulinlike growth factor (IGF) receptors. Insulin and IGFs belong to a family of peptide hormones which share structural and functional homology $(10,11)$. The recent availability of large amounts of pure IGFs, the cloning and expression of the insulin and IGF receptors, and the production of antibodies specific for these receptors have made it possible to compare the specific actions of these peptide hormones when they are known to be acting through their homologous receptor. The accumulating evidence suggests that insulin and IGF receptors mediate many of the same acute and

1. Abbreviations used in this paper: IGF, insulinlike growth factor; $I_{\mathbf{s c}}$, short-circuit current; LDH, lactate dehydrogenase; NECA, $N$-ethylcarboxamido-adenosine. 
chronic responses, although with varying degrees of efficacy depending on the tissue or cell type and the specific response under study (10-16). Thus the simplistic idea that insulin mediates acute metabolic responses, while IGFs mediate chronic mitogenic responses is not strictly correct in vitro, but may still be true in vivo due to marked differences between insulin and IGF secretion, localization and turnover $(10,11)$.

In this article we show that the effect of insulin on transepithelial resistance across $\mathrm{T} 84$ cell monolayers is receptor mediated and due exclusively to an effect on the tight junctionmediated paracellular pathway. In the A6 toad kidney cell line, Fidelman and Watlington (17) found that insulin in combination with aldosterone markedly increased paracellular permeability, however, in this cell line the effects were complicated by a large increase in active $\mathrm{Na}^{+}$absorption. Regulation of paracellular permeability has recently received increasing attention as potentially important mechanism for the control of solute and water absorption and secretion (18). A number of biologically important factors including phorbol esters (19), Clostridium difficile enterotoxin A (20), interferon- $\gamma(21)$, and neutrophil-derived cathepsin $G(22)$ have been shown to alter the permeability of the tight junctional paracellular pathway. The potential physiologic role of insulin and related factors in regulation of intestinal permeability is discussed.

\section{Methods}

Cell culture. T84 cells used in this study are descendents of those originally obtained from Dr. Hideo Masui (University of California, San Diego) after one passage in nude mice and nine passages in culture. Cells from passages 14-44 were used in the present study. T84 cells were serially propagated by weekly subculture using established methodologies $(4,5)$. Unless otherwise indicated, growth media consisted of a 1:1 mixture of Dulbecco-Vogt modified Eagle's media (high glucose) and Ham's F12 media supplemented with $15 \mathrm{mM} \mathrm{Na}^{+}$-Hepes buffer, pH $7.4,90 \mathrm{mg} /$ liter streptomycin, $40 \mathrm{mg} /$ liter penicillin, $8 \mathrm{mg} / \mathrm{liter}$ ampicillin, and $5 \%$ newborn calf serum. Media $\mathrm{NaHCO}_{3}$ concentration was $1.2 \mathrm{~g} /$ liter and cell cultures were maintained in incubators under $5 \% \mathrm{CO}_{2}$. The insulin levels in the two lots of serum used in these experiments was 0.150 and $0.162 \mathrm{ng} / \mathrm{ml}$ (by radioimmunoassay), giving final concentrations in the growth media of $\leq 0.0081 \mathrm{ng} / \mathrm{ml}$. For preparation of monolayers on permeable supports, trypsinized cell suspensions containing $1-1.5 \times 10^{6}$ cells were added to the inside of filter bottom cups and maintained in culture with media changes every 3-4 d. Filter bottom cups were prepared as described previously (5). Briefly, 5- $\mu \mathrm{m}$ pore size Nuclepore filters (Nuclepore Corp., Pleasanton, CA) were coated with rat tail collagen (Collaborative Research Inc., Bedford, MA), cross-linked with $4 \%$ glutaraldehyde, and glued to plastic Lexan rings. The final growth area of the filter cups was $1.98 \mathrm{~cm}^{2}$.

$\mathrm{CaCO}_{2}, \mathrm{HCT}-8$, and LLC-PK 1 cells were obtained from the American Type Culture Collection, Rockville, MD. The MDCK cell line used (clone D1) was obtained from Dr. Paul Insel (University of California, San Diego). All cell lines were adapted to the same culture conditions used for T84 cells (DME/Ham's F12, 1:1, supplemented with $5 \%$ newborn calf serum).

Resistance and transepithelial flux measurements. For measurement of electrical resistance, monolayers attached to the filter bottom cups were rinsed in oxygenated Ringer solution and mounted in modified Ussing chambers. The Ussing chamber apparatus was identical to that previously described (4) except that the potential difference sensing agar bridges were mounted at an angle such that the tips approached within $2 \mathrm{~mm}$ of the center of the monolayers. This adaptation was introduced to reduce the fluid resistance compensation and permit more accurate measurement of low resistance monolayers. Edge damage to the monolayers was avoided by mounting the entire ring assembly with no pressure being exerted directly on the cell monolayers. Both reservoirs of the Ussing chamber were filled with identical volumes of oxygenated Ringer solution which contained (in millimolar): $140 \mathrm{Na}, 5 \mathrm{~K}, 1.2 \mathrm{Ca}, 1.2 \mathrm{Mg}, 119.8 \mathrm{Cl}, 25 \mathrm{HCO}_{3}, 2.4 \mathrm{H}_{2} \mathrm{PO}_{4}, 0.4$ $\mathrm{HPO}_{4}$, and 10 glucose. An airlift system using $95 \% \mathrm{O}_{2}$ and $5 \% \mathrm{CO}_{2}$ was used for mixing, oxygenation and buffering (pH 7.4). The entire apparatus was water-jacketed such that the solutions bathing the monolayers were maintained at $36-37^{\circ} \mathrm{C}$. The potential difference was measured using calomel electrodes in $3 \mathrm{M} \mathrm{KCl}$ connected to the chamber through agar bridges. Spontaneous potential difference was short-circuited and nullified using an automatic voltage clamp (Physiological Instruments, San Diego, $\mathrm{CA}$ ) with $\mathrm{Ag}-\mathrm{AgCl}$ current supplying electrodes connected to the chamber with agar bridges. Short-circuit current was monitored throughout the experiment. Resistance measurements were made every 5 min by briefly $(5 \mathrm{~s})$ clamping the potential difference to a known voltage and measuring the current necessary to produce this deflection. Resistance and conductance was calculated from Ohm's law. While there was a great deal of variation in the level of resistance across untreated (control) monolayers, most of this variation could be attributed to different batches of permeable supports or varying passage numbers of the cells. When feasible, each set of experiments was performed on monolayers prepared with cells of similar passage number grown on the same batch of permeable supports, allowing direct comparison of resistance levels. When this was not possible, resistance values were normalized to the same day control monolayers.

For the ${ }^{22} \mathrm{Na},\left[{ }^{3} \mathrm{H}\right]$ mannitol dual flux analysis, monolayers were rinsed and mounted with Ringers solution containing $5 \mathrm{mM}$ mannitol and $5 \mathrm{mM}$ glucose on both sides of the monolayer. After the electrical properties of the monolayers had stabilized, $1 \mu \mathrm{Ci} / \mathrm{ml}{ }^{22} \mathrm{Na}$ and 5 $\mu \mathrm{Ci} / \mathrm{ml} \mathrm{D}-\left[{ }^{3} \mathrm{H}\right]$ mannitol were added to either the serosal or mucosal bathing solutions. After a 2-min mixing period, a small sample was removed from the hot side for determination of specific activity. Thereafter samples were removed from the opposite reservoir at 10min intervals with buffer replacement. The activity of ${ }^{22} \mathrm{Na}$ and $\left[{ }^{3} \mathrm{H}\right]-$ mannitol in the samples was quantitated by differential scintillation counting. After correction for sample volume and isotope loss due to sampling the results of at least four consecutive 10-min flux periods were averaged. All fluxes were measured under short-circuited conditions.

Transepithelial resistance of monolayers in growth media was also monitored with an EVOM volt-ohmmeter (World Precision Instruments, New Haven, CT) which measures resistance by passing alternating current across the monolayers. The potential and current electrodes of this apparatus can be sterilized allowing repeated measurements of the same monolayer over a period of weeks. For monolayers with resistances $\leq 1,500 \Omega-\mathrm{cm}^{2}$, this apparatus gave transepithelial resistance values similar to those obtained when the monolayers were subsequently mounted in Ussing chambers. ${ }^{2}$ At higher levels of resistance the EVOM measurements were progressively lower than those measured in voltage-clamped Ussing chambers. Therefore, except for figure 2 and as noted in the text, all resistance values reported were determined after mounting in voltage-clamped Ussing chambers.

Actin filament staining with rhodamine-labeled phalloidin. T84 cells were grown to confluency on glass coverslips, washed twice with Dulbecco's phosphate-buffered saline (PBS) and fixed with freshly prepared $3.7 \%$ formaldahyde in PBS for $10 \mathrm{~min}$ at room temperature. After two washes with PBS, the specimens were extracted with acetone at $-20^{\circ} \mathrm{C}$ for $10 \mathrm{~min}$ and air dried. The cells were incubated in the dark for $30 \mathrm{~min}$ with $0.165 \mu \mathrm{M}$ rhodamine-labeled phalloidin (Molecular Probes, Junction City, OR) in PBS which was prepared by drying the methanolic stock solution under $\mathrm{N}_{2}$ and dissolving in PBS immedi-

2. For 99 monolayers with resistances $\leq 1,500 \Omega-\mathrm{cm}^{2}$, a plot of resistance determined in voltage-clamped Ussing chambers versus resistance determined in situ with the EVOM gave a slope of 0.94 with a correlation coefficient of 0.96 . 
ately prior to the staining procedure. The coverslips were washed three times with PBS, mounted on slides with a 1:1 solution of PBS and glycerol and the edges sealed with nail polish. Observations and photographs were made using a Nikon Inc. Diaphot microscope (Garden City, NY) equipped for epifluorescence, a rhodamine filter, and Tri-X pan 400 film (Eastman Kodak Co., Rochester, NY).

Biological assays. Media levels of lactate dehydrogenase and glucose were measured spectophotometrically using assay kits from Sigma Chemical Co., St. Louis, MO. Intracellular lactate dehydrogenase was determined after lysing the cells with $1 \%$ Triton X-100.

Leucine incorporation into cellular protein was measured using replicate $35-\mathrm{mm}$ plates of confluent $\mathrm{T} 84$ cells and monolayers grown on permeable supports. Cells were incubated in growth media containing $1 \mu \mathrm{Ci} / \mathrm{ml}\left[{ }^{3} \mathrm{H}\right]$ leucine in the presence or absence of $3 \mu \mathrm{g} / \mathrm{ml}$ insulin and $2 \mu \mathrm{M}$ cycloheximide for $6-24-\mathrm{h}$ periods after which the monolayers were washed with PBS and lysed by the addition of $0.075 \%$ SDS. Protein was precipitated by the addition of ice cold $10 \%$ (final) TCA and collected by centrifugation. The pellet was dissolved in $0.5 \mathrm{~N}$ $\mathrm{NaOH}$ and counted. All determinations were made in triplicate and the results cited represent the mean determinations from four experiments for each condition.

Cell numbers were determined by a cell counter (Coulter Electronics, Inc., Hialeah, FL) after extensive (45 min) trypsinization of confluent monolayers on permeable supports and appropriate dilution. Values were corroborated using a hemocytometer. Total cellular DNA was determined fluorometrically (23) using calf thymus DNA as a standard.

Materials. Bovine insulins were obtained from Sigma Chemical Co. (Fig. 1 only), Boehringer Mannheim (>99\%, $26 \mathrm{IU} / \mathrm{mg}$ ), and Collaborative Research Inc. (99\%, 28.4 IU/mg). DME and Ham's F12 media were purchased from Gibco Laboratories, Grand Island, NY, and the newborn bovine serum from Irvine Scientific, Santa Ana, CA. ${ }^{22} \mathrm{Na}$ was from New England Nuclear, Boston, MA, $\left[{ }^{3} \mathrm{H}\right]$ leucine from Amersham Corp., Arlington Heights, IL, and D- $\left[{ }^{3} \mathrm{H}\right]$ mannitol from ICN, Irvine, CA. Transferrin, forskolin, cycloheximide, $N$-ethylcarboxamido-adenosine, and calf thymus DNA were purchased from Sigma Chemical Co. Sodium selenite came from Difco Laboratories, Detroit, MI.

Statistical methods. Significance was determined using Student's unpaired $t$ test. When more than two groups were compared, the $P$ values cited include Bonferroni correction.

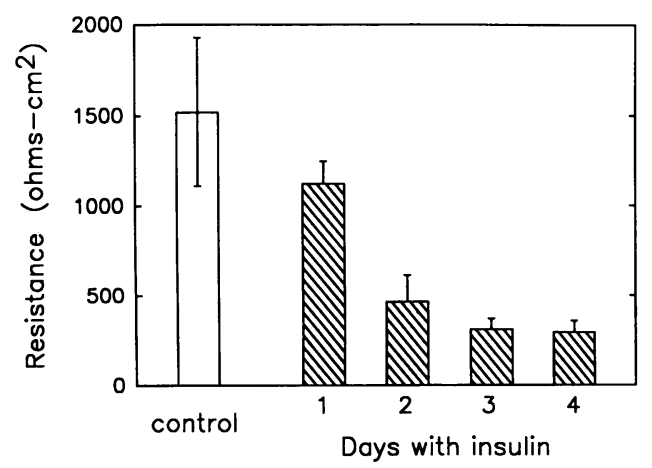

Figure 1. Time-dependent effect of insulin on T84 cell monolayer resistance. Established, high-resistance T84 cell monolayers received fresh media containing either $15 \mu \mathrm{g} / \mathrm{ml}$ Sigma insulin (hatched bars) or no addition (open bars). At various times after the media change, the insulin-treated monolayers and at least one control monolayer were mounted in voltage-clamped Ussing chambers where resistance measurements were made as described in Methods. The values shown are the mean $\pm S D$ of at least three monolayers for each day. Control monolayers $(n=9)$ did not vary in resistance with time. Significant effects occurred after $2 \mathrm{~d}(P<0.002)$ and maximal effects after $3 \mathrm{~d}(P<0.0006)$.

\section{Results}

Temporal dependence and metabolic effects. T84 cell monolayers develop a transepithelial resistance of $>1,000 \Omega-\mathrm{cm}^{2}$ over the course of a week when grown and maintained in serum supplemented media on permeable supports. High resistance can be maintained for over 3 wk with media changes every 3-4 d. The addition of insulin at a concentration typically used in defined media $(3 \mu \mathrm{g} / \mathrm{ml})$ to preestablished monolayers in the continued presence of serum supplement caused the transepithelial resistance to decline from $1,760 \pm 780$ to $210 \pm 160 \Omega-\mathrm{cm}^{2}\left(n=23\right.$ pairs, $\left.P<10^{-6}\right)$. This insulin mediated decline in transepithelial resistance required 3-4 $d$ to reach maximal effects. Even at high concentrations $(15 \mu \mathrm{g} / \mathrm{ml})$ the decline in resistance was not significant until $2 \mathrm{~d}$ after addition (Fig. 1). Stable low levels of resistance were observed after $4 \mathrm{~d}$ at all doses of insulin as judged by in situ (EVOM) resistance measurements. This effect was not due to a permissive interaction with a factor in the serum supplement since addition of $3 \mu \mathrm{g} / \mathrm{ml}$ insulin to preestablished monolayers maintained under serum-free conditions (DME:Ham's F12, $1: 1$, plus $5 \mu \mathrm{g} / \mathrm{ml}$ transferrin and $25 \mathrm{nM}$ selenium) also produced a significant decline in resistance over a 3-d time course $\left(1,530 \pm 220\right.$ for control and $360 \pm 210 \Omega-\mathrm{cm}^{2}$ for insulin treated monolayers; $n=6$ pairs, $P<0.0003$ ).

The large insulin-induced decline in transepithelial resistance was not due to cell death since media levels of lactate dehydrogenase $(\mathrm{LDH})$ relative to intracellular $\mathrm{LDH}$ levels were not increased after $4 \mathrm{~d}$ of treatment with $3 \mu \mathrm{g} / \mathrm{ml}$ insulin. Total extracellular LDH relative to intracellular $\mathrm{LDH}$ was $9.4 \pm 2.5 \%$ for control conditions and $10.1 \pm 2.3 \%$ for insulintreated cells. Furthermore, insulin-treated monolayers were still responsive to secretagogues. Table $I$ shows the $I_{\mathrm{sc}}$ response of insulin-treated monolayers to forskolin and the adenosine receptor agonist, $N$-ethylcarboxamido-adenosine (NECA). In both cases, the $I_{\mathrm{sc}}$ response to these compounds has been shown to reflect electrogenic $\mathrm{Cl}^{-}$secretion $(6,24)$, a process which is inhibited by serosal side addition of the loop diuretic bumetanide (5). The $I_{\mathrm{sc}}$ response of insulin-treated monolayers was still sensitive ( $\sim 80 \%$ inhibition) to $10^{-4} \mathrm{M}$ bumetanide suggesting that insulin did not modify the mechanisms of hormonally stimulated electrogenic ion movement. However, as shown in Table I, monolayers treated with insulin for $4 \mathrm{~d}$ with no media change had a diminished level of secretagogue responsiveness. This effect could be prevented with daily media changes (Table I). Daily media changes did not attenuate the insulin-induced decline in transcellular resistance, arguing against an indirect effect of insulin on resistance.

Insulin failed to stimulate cell division by confluent established monolayers on permeable supports, even though previous studies have shown that insulin is mitogenic for T84 cells grown at low density in serum-free media (1). There was no change in the final cell density $\left(1.18 \pm 0.21 \times 10^{6}\right.$ and $1.38 \pm 0.29 \times 10^{6}$ cells/monolayer, $n=6$ ) or total DNA content (32.3 \pm 4.4 and 32.6 $\pm 4.5 \mu \mathrm{g}$ DNA/monolayer, $n=7$, for control and insulin-treated tissues, respectively) of monolayers treated for $4 \mathrm{~d}$ with $3 \mu \mathrm{g} / \mathrm{ml}$ insulin. Insulin did stimulate an increase in glucose catabolism as judged by media glucose levels which declined from $17.5 \pm 0.3 \mathrm{mM}$ in fresh media to $15.7 \pm 0.2 \mathrm{mM}$ in control and $13.2 \pm 0.3 \mathrm{mM}$ in insulin-treated monolayers after $4 \mathrm{~d}$ in culture $(n=6, P<0.001)$. Insulin also stimulated a modest $16.4 \pm 7.3 \%$ increase in the rate of protein 
Table I. Effect of Daily Media Change on Transepithelial Resistance and Short-Circuit Current Response to Secretagogues

\begin{tabular}{|c|c|c|c|c|}
\hline Condition $(n)$ & Initial resistance & Initial $I_{\mathbf{x c}}$ & $\begin{array}{c}\Delta I_{s c} \\
1 \mu \mathrm{M} \\
(\mathrm{NECA})\end{array}$ & $\begin{array}{c}\Delta I_{\mathbf{s c}} \\
10 \mu \mathrm{M} \\
\text { (forskolin) }\end{array}$ \\
\hline & $\Omega-\mathrm{cm}^{2}$ & $\mu \mathrm{A} / \mathrm{cm}^{2}$ & $\mu \mathrm{A} / \mathrm{cm}^{2}$ & $\mu A / \mathrm{cm}^{2}$ \\
\hline \multicolumn{5}{|l|}{ No media change } \\
\hline Control (5) & $1530 \pm 420$ & $1.2 \pm 0.3$ & $22.4 \pm 12.0$ & $39.2 \pm 18.5$ \\
\hline Insulin (7) & $220 \pm 150^{\ddagger}$ & $0.9 \pm 1.6$ & $8.9 \pm 5.2^{*}$ & $20.5 \pm 7.1^{*}$ \\
\hline \multicolumn{5}{|c|}{ Daily media change } \\
\hline Control (3) & $1640 \pm 100$ & $3.1 \pm 2.8$ & $24.5 \pm 8.5$ & $35.6 \pm 7.8$ \\
\hline Insulin (3) & $110 \pm 40^{\ddagger}$ & $1.6 \pm 1.4$ & $22.5 \pm 11.9$ & $39.1 \pm 14.0$ \\
\hline
\end{tabular}

Replicate preestablished T84 cell monolayers received either insulin $(3 \mu \mathrm{g} / \mathrm{ml})$ or no addition (control). The media (a total of $5 \mathrm{ml} / \mathrm{monolayer})$ was either left on the cells for $4 \mathrm{~d}$ (no media change) or changed on a daily basis. After $4 \mathrm{~d}$ the monolayers were mounted in Ussing chambers and voltage clamped. Initial resistance and $I_{\mathrm{sc}}$ measurements were recorded over a 25 -min period after which time $1 \mu \mathrm{M}$ NECA was added to the mucosal side of the monolayers. $I_{\mathrm{sc}}$ was monitored until peak values were observed, then $10 \mu \mathrm{M}$ forskolin was added to the serosal side and $I_{\mathrm{sc}}$ again monitored until it reached peak values. $\Delta I_{\mathrm{sc}}$ represents the difference between peak values recorded after NECA and forskolin addition and the initial $I_{\mathrm{sc}}$ reading. Values are the mean $\pm \mathrm{SD}$ of $n$ monolayers for each condition. Significantly different from control: ${ }^{*} P<0.04$; ${ }^{\ddagger} P<0.0001$. In the no media change condition, the effect of insulin in decreasing the Isc response to NECA and forskolin was more pronounced when compared to the same day control monolayers: NECA and forskolin produced relative $\Delta I_{\mathrm{sc}}$ responses of $50 \pm 12 \%(P<0.0001)$ and $59 \pm 14 \%(P<0.0003)$ that of control, respectively.

synthesis as assessed by $\left[{ }^{3} \mathrm{H}\right]$ leucine incorporation into TCAprecipitable protein. Thus, the effect of insulin appears to be confined to increased metabolism and increased protein synthesis, accompanied by a pronounced decrease in transcellular resistance.

Inhibition by cycloheximide. The long time course of the effect of insulin and the increased rate of protein synthesis prompted us to test whether protein synthesis might be involved in this response. The addition of $2 \mu \mathrm{M}$ cycloheximide, a concentration sufficient to inhibit protein synthesis by $\sim 75 \%$, prevented insulin's effect on resistance. In this set of experiments, control monolayers had resistances of $1390 \pm 260$ (n $=9$ ), while monolayers treated with $3 \mu \mathrm{g} / \mathrm{ml}$ insulin for $4 \mathrm{~d}$ had resistances of $150 \pm 130 \Omega-\mathrm{cm}^{2}(n=7)$. Addition of $2 \mu \mathrm{M}$ cycloheximide alone for $4 \mathrm{~d}$ tended to increase resistance, but not significantly $\left(1,790 \pm 560 \Omega-\mathrm{cm}^{2}, n=9 ; P \sim 0.4\right)$. When added simultaneously, the combination of $3 \mu \mathrm{g} / \mathrm{ml}$ insulin and $2 \mu \mathrm{M}$ cycloheximide caused a significant increase in transepithelial resistance $\left(2,790 \pm 690 \Omega-\mathrm{cm}^{2}, n=7 ; P<0.001\right.$ vs. control, $P$ $<0.03$ vs. cycloheximide alone). There was no effect of cycloheximide treatment on the secretagogue responsiveness of the monolayers (data not shown). These results suggest that protein synthesis is required to produce the insulin-mediated decline in transcellular resistance. They also suggest that in the presence of reduced levels of protein synthesis, insulin can mediate the opposite effect on paracellular permeability.

Reversibility. The effect of insulin on transepithelial resistance was reversible, although with a much slower time course than that required for the onset of insulin action. Recovery of transepithelial resistance after treatment of cells for $4 \mathrm{~d}$ with 3 $\mu \mathrm{g} / \mathrm{ml}$ insulin began $\sim 5 \mathrm{~d}$ after removal of insulin. Full recovery of resistance was obtained after 9-10 d in insulin-free media. Fig. 2 shows the results of a representative experiment. In three similar experiments, resistance recovered to $\sim 102 \pm 14 \%$ that of control monolayers after washout of insulin for 9-10 d.

Receptor polarization and dose dependence. T84 monolayers grown on permeable supports are structurally and functionally polarized with distinct apical and basolateral mem- branes. With the exception of the adenosine receptor, most hormone receptors are polarized to the basolateral membrane (6). If insulin is mediating its effect through a receptor, one would expect functional polarization of the responsiveness to insulin. Indeed, addition of $0.3 \mu \mathrm{g} / \mathrm{ml}$ insulin to the serosal (basolateral membrane) side only of $\mathrm{T} 84$ cell monolayers produced a 4-d decline in resistance (from 1,630 2500 to $150 \pm 110$ $\Omega-\mathrm{cm}^{2}$ for control and serosal addition, respectively) similar to that produced by combined mucosal and serosal addition

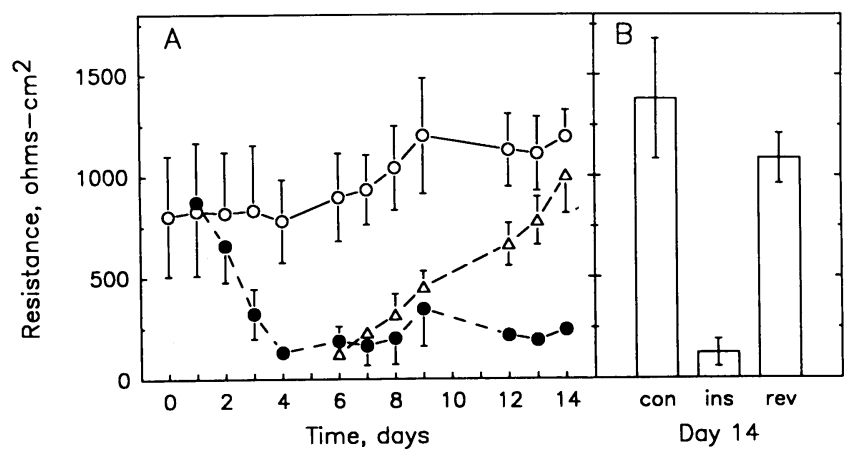

Figure 2. Reversibility of the insulin-induced decline in resistance. $(A)$ Time course of the onset and reversal of insulin's effect on resistance determined in situ with the EVOM. Nine 7-d-old monolayers were assigned to three groups of three within which the average resistance values were similar. On day 0 , six of the monolayers received 3 $\mu \mathrm{g} / \mathrm{ml}$ purified insulin $(\bullet)$, while the remaining three monolayers were left as controls and received no addition (0). On day 4, three of the six monolayers treated with insulin were washed twice and incubated with insulin-free media $(\Delta)$. Media was changed on all monolayers every 3-4 d. Points are the mean and error bars the SD for each group (three to nine monolayers). Background resistance of 70 $\Omega-\mathrm{cm}^{2}$ has been subtracted from these EVOM measurements. $(B)$ Voltage clamp determinations of resistance on day 14 for all three groups of monolayers. The nine monolayers in this representative experiment were rinsed with Ringer buffer and mounted in Ussing chambers as described in Methods: con, control; ins, insulin-treated; and rev, reversed. 
$\left(390 \pm 320 \Omega\right.$ - $\left.\mathrm{cm}^{2}\right)$. Addition to the mucosal (apical membrane) side only had no significant effect $\left(1,370 \pm 490 \Omega-\mathrm{cm}^{2}, n=6\right.$ for all values). These results suggest that the insulin induced decline in transcellular resistance is receptor-mediated and that the receptors are localized in the basolateral membrane.

The dose dependence of insulin on transepithelial resistance supports this conclusion. As shown in Fig. 3, highly purified bovine insulins from two sources produced similar dose response curves with half-maximal effects at $\sim 3.9 \mathrm{ng} / \mathrm{ml}$ $(0.68 \mathrm{nM})$ and maximal effects at $300 \mathrm{ng} / \mathrm{ml}$. The broad nature of the dose-dependent effect of insulin on resistance (apparent Hill slope 0.7 ) suggests negative cooperativity or perhaps multiple receptor subtypes.

Paracellular permeability. A decrease in transepithelial electrical resistance could be due to an increase in the cellular ionic permeability or increase in the paracellular ionic permeability. To distinguish between these two possibilities, simultaneous measurements of the transepithelial flux of $\left[{ }^{3} \mathrm{H}\right]$ mannitol and ${ }^{22} \mathrm{Na}$ were made on monolayers treated with varying concentrations of insulin for $4 \mathrm{~d}$. Mannitol is poorly absorbed by cells and transport across the epithelial layer takes place around the cells through the tight junction-mediated paracellular pathway. If one assumes that the paracellular pathway is an aqueous channel with no charge selectivity, then the change in the unidirectional flux of $\mathrm{Na}\left(\Delta J_{\mathrm{Na}}\right)$ relative to that for mannitol $\left(\Delta J_{\operatorname{man}}\right)$ can be predicted (25): $\Delta J_{\mathrm{Na}} / \Delta J_{\operatorname{man}}$ $=D_{\mathrm{Na}} \cdot[\mathrm{Na}] / D_{\operatorname{man}} \cdot$ [mannitol], where $D_{\mathrm{Na}}$ and $D_{\operatorname{man}}$ are the diffusion coefficients and [Na] and [mannitol] are the molar concentrations of $\mathrm{Na}$ and mannitol, respectively. At $37^{\circ} \mathrm{C}$ in buffers containing $140 \mathrm{mM} \mathrm{Na}$ and $5 \mathrm{mM}$ mannitol the predicted value is $54(26)$. A plot of $J_{\mathrm{Na}}$ vs. $J_{\operatorname{man}}$ for 36 monolayers treated for $\mathbf{4} \mathrm{d}$ with varying concentrations of insulin is shown in Fig. 4. Unidirectional fluxes were determined in half the monolayers in the serosal to mucosal direction and in the

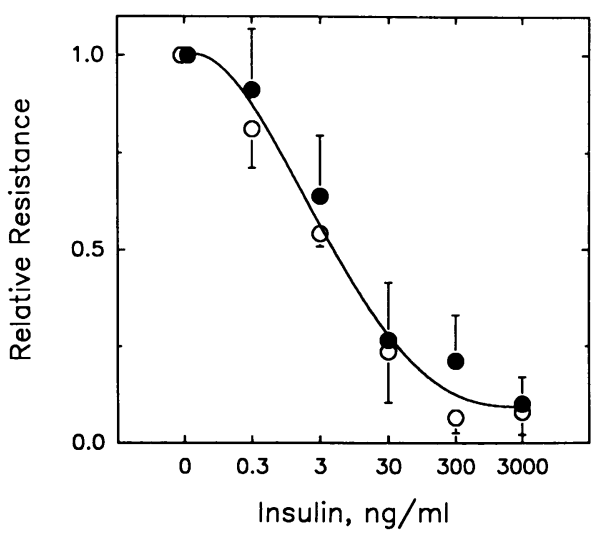

Figure 3. Dose-dependent effect of insulin on transepithelial resistance. T84 cell monolayers were treated with various concentrations of highly purified bovine insulin obtained from either Boehringer Mannheim (o) or Collaborative Research, Inc. (๑). After $4 \mathrm{~d}$ the insulin treated and control monolayers were mounted in Ussing chambers for resistance measurements. The results were normalized to the same day control monolayers. Points are the mean \pm SD of four ( 0 ) and six (๑) monolayers for each concentration. Nonlinear regression gave $\mathrm{ED}_{50}$ values of 3.2 and $4.3 \mathrm{ng} / \mathrm{ml}$ with a Hill slope coefficients of 0.63 and 0.81 for insulin from Boehringer Mannheim or Collaborative Research, Inc. respectively. The curve shown was obtained from the average values for both insulins: $\mathrm{ED}_{50}=3.9$, Hill slope coefficient $=0.70$.

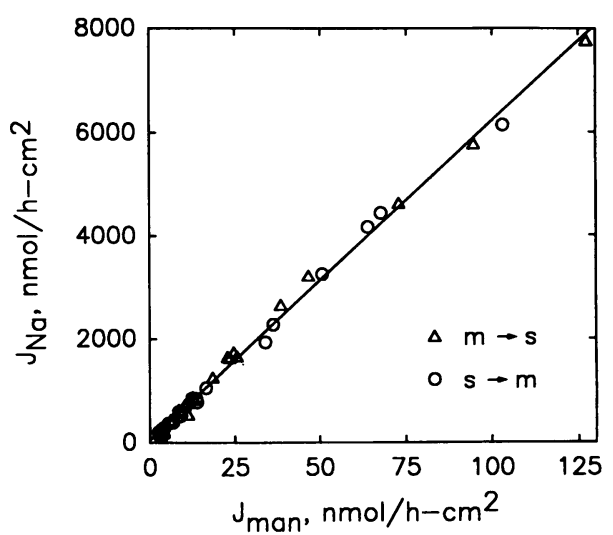

Figure 4. Dual flux analysis demonstrating an effect of insulin on paracellular permeability. Simultaneous mucosal to serosal $(m \rightarrow s$, o) and serosal to mucosal $(s \rightarrow m, \Delta)$ fluxes of ${ }^{22} \mathrm{Na}$ and ${ }^{3} \mathrm{H}$ were determined on control monolayers and monolayers receiving various $(0.3 \mathrm{ng} / \mathrm{ml}$ to $3 \mu \mathrm{g} / \mathrm{ml})$ concentrations of insulin for $4 \mathrm{~d}$. Flux rates were determined as described in Methods during four 10-min intervals and averaged for each point. Linear regression of the $m \rightarrow s$ and $s \rightarrow m$ determinations gave slopes of $61.6(r=0.998)$ and $61.8(r$

$=0.998$ ), respectively.

other half in the serosal to mucosal direction. The slope of the lines, which give the ratio of $\Delta J_{\mathrm{Na}} / \Delta J_{\text {man }}$, in both cases gave nearly identical values of $\sim 62$. These values are significantly different from the predicted value of $54(P<0.0001)$. This could be taken as evidence for a small increase in the cellular transport of $\mathrm{Na}^{+}$. However, since there was no difference between the ratios of $\Delta J_{\mathrm{Na}} / \Delta J_{\operatorname{man}}$ determined in the mucosal to serosal and the serosal to mucosal directions, there is no evidence for a change in the net transport of $\mathrm{Na}^{+}$. Because the $\mathrm{Na}^{+}, \mathrm{K}^{+}$ATPase is localized to the basolateral membrane of these cells, one would expect a net absorptive flux of $\mathrm{Na}^{+}$if there were any change in the apical membrane permeability of these monolayers to $\mathrm{Na}^{+}$. Therefore, this deviation from the predicted value cannot be explained by increased cellular $\mathrm{Na}^{+}$ transport and probably arises from the heterogeneity or selectivity of the tight junctional pores. This conclusion is supported by the earlier observation that insulin does not change the $\mathrm{Cl}^{-}$secretory nature of this model epithelium.

From the data generated in the dual flux analysis, we were also able to construct dose-response curves for the effect of insulin on increased mannitol and sodium flux (Fig. 5). Insulin increased the unidirectional flux of $\mathrm{Na}^{+}$and mannitol in a manner that paralleled the increase in conductance. Because the reciprocal nature of conductance to resistance, the half maximally effective concentrations were considerably higher than that found to decrease resistance $(\sim 63 \mathrm{ng} / \mathrm{ml}$ for all three parameters, see Fig. 5 legend for details).

Morphological alterations in the perijunctional actin ring. A number of recent investigations have demonstrated parallel changes in paracellular permeability and the structure of the peri-junctional actin ring which underlines the tight junction at the level of the adhering junction or belt desmosomes $(20$, 21, 26-29). To determine if a similar change in cytoskeletal structure was induced by insulin, T84 cell monolayers were fixed and stained with rhodamine-labeled phalloidin. Phalloidin is a fungal toxin which binds to filamentous actin with high affinity. Monolayers stained with rhodamine-labeled phalloidin were visualized by epiflorescence microscopy. Un- 


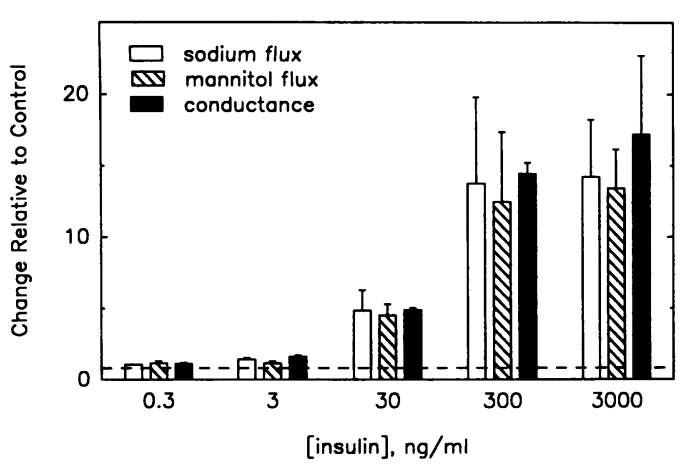

Figure 5. Dose-dependent effect of insulin on $\mathrm{Na}^{+}$flux (open bars), mannitol flux (hatched bars), and conductance (solid bars). The same data used to generate Fig. 4 are replotted as a function of insulin concentration after first normalizing each parameter to the same day control value and lumping the results of the $m \rightarrow s$ and $s \rightarrow m$ fluxes together. The mean control $\mathrm{Na}^{+}$and mannitol flux rates were $302 \pm 184$ and $4.60 \pm 2.43 \mu \mathrm{eq} / \mathrm{h} / \mathrm{cm}^{2}$, respectively, and the mean control conductance $0.920 \pm 0.383 \mathrm{mS} / \mathrm{cm}^{2}$ (indicated as the dotted horizontal line $=1$ ). Values shown represent the mean $\pm S D$ of six monolayers. Nonlinear regression analysis gave $\mathrm{ED}_{50}$ values of 51,58 , and $73 \mathrm{ng} / \mathrm{ml}$; Hill slope coefficients of 1.7, 1.3, and 1.1; and maximal relative stimulation values of 14-, 14-, and 17-fold for increased $\mathrm{Na}^{+}$ flux, mannitol flux, and conductance, respectively. The $\mathrm{ED}_{50}$ value for all three parameters lumped together was $63 \mathrm{ng} / \mathrm{ml}$ with a Hill slope coefficient of 1.3 and maximal increase of 15 -fold.

treated, control monolayers had uniformly stained actin "rings" which followed the contours of the cells (Fig. 6, top panel). While there was no gross alteration in this structure in monolayers treated with $3 \mu \mathrm{g} / \mathrm{ml}$ insulin for $4 \mathrm{~d}$ (Fig. 6, bottom panel), the structures did appear to be less distinct with numerous focal condensations. This pattern of condensation is remarkably similar to that found after treatment of T84 cells with interferon- $\gamma$ (27). In fact, the time course and efficacy of insulin's effect on T84 cells parallels that described for interferon- $\gamma$. These observations suggest that insulin and interferon- $\gamma$ may be acting through similar mechanisms to alter the structure of the actin ring and change paracellular permeability.

Generality of the insulin effect. We have investigated whether insulin mediates a similar effect on transepithelial resistance in other established epithelial cell lines. Two carcinoma-derived human intestinal cell lines, $\mathrm{CaCO}_{2}$ and $\mathrm{HCT}-8$, responded to high-dose insulin $(3 \mu \mathrm{g} / \mathrm{ml})$ with significant decline in transepithelial resistance (Table II). Two "normal" kidney-derived cell lines, MDCK and LLC-PK1, did not display this response. In none of the cells tested did insulin alter the basal $I_{s c}$, demonstrating that the hormone was not inducing electrogenic ion movement.

\section{Discussion}

When added to established high-resistance monolayers of the colonic T84 epithelial cell line, insulin causes a time- and dose-dependent decrease in the transepithelial resistance. The effect of insulin on transepithelial resistance is due exclusively to an increase in the permeability of the paracellular pathway, as evidenced by parallel increases in the unidirectional flux rates for $\mathrm{Na}^{+}$and the extracellular space marker mannitol. Although the change in the unidirectional flux of mannitol relative to $\mathrm{Na}^{+}$deviates significantly from that predicted for
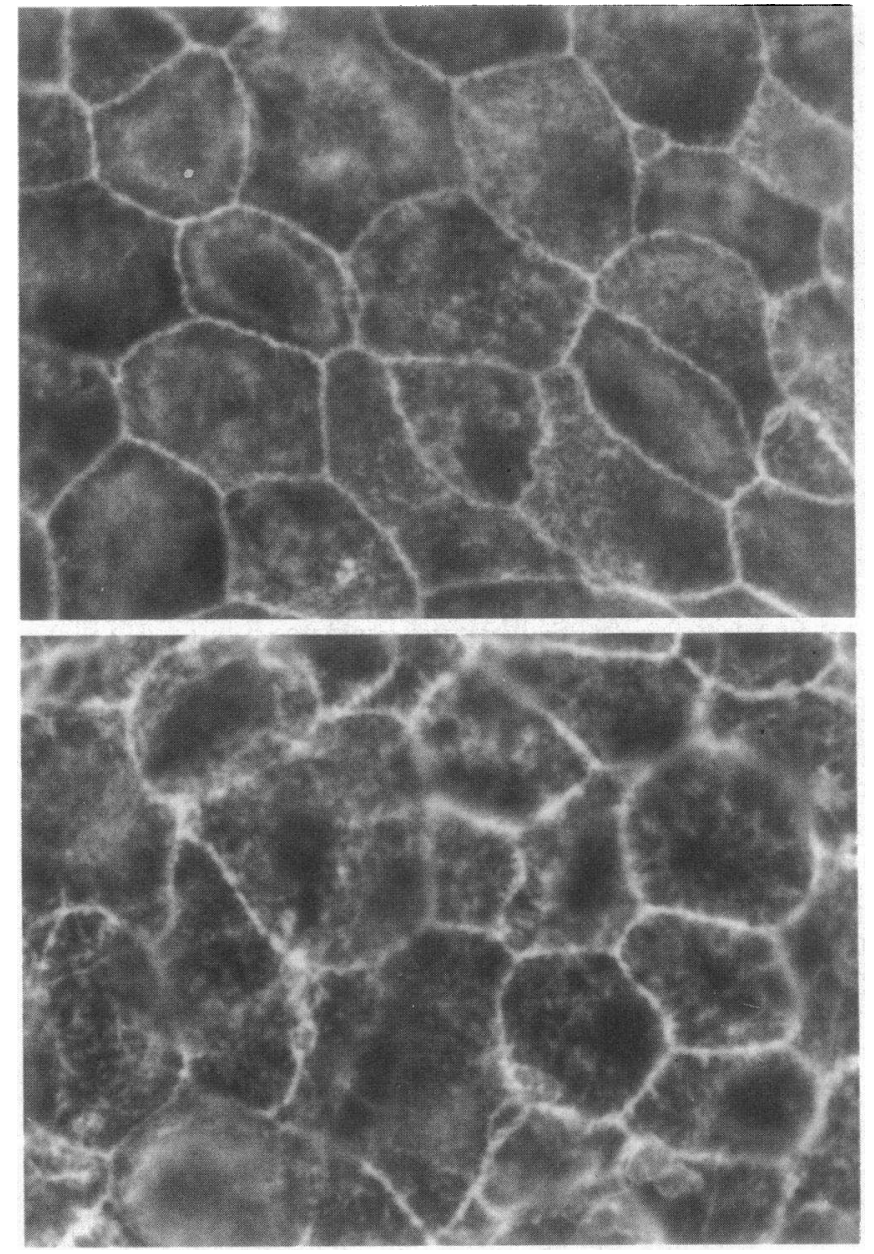

Figure 6. Rhodamine-labeled phalloidin staining of the peri-junctional actin rings of T84 cells. Cell monolayers were fixed, stained and visualized by epifluorescent microscopy as described in Methods. (Top panel) Control T84 cells grown to confluency on glass coverslips. (Bottom panel) T84 cells plated at the same time as control but treated for $4 \mathrm{~d}$ with $3 \mu \mathrm{g} / \mathrm{ml}$ insulin. In both cases media changes were made on a daily basis. Magnification $\sim \times 800$.

diffusion of molecules through an aqueous environment, this deviation is probably due to heterogeneity or selectivity of the tight junctional "pores." This conclusion was based on the observation that there was no apparent change in the net flux of $\mathrm{Na}^{+}$which would be expected if insulin had induced changes in the cellular transport pathways for $\mathrm{Na}^{+}$. This result is in marked contrast to mammalian distal kidney, amphibian skin, colon and urinary bladder as well as the toad kidney-derived $\mathrm{A} 6$ cell line where insulin has been shown to induce active electrogenic $\mathrm{Na}^{+}$absorption (30-34).

Regulation of epithelial paracellular permeability has only recently been recognized as an important regulatory mechanism for the control of solute and water flux across epithelium. A number of biologically important factors including interferon- $\gamma$ (21), cathepsin G (22), Clostridium difficile toxin A (20), and phorbol esters $(19,29)$, as well as changes in the intracellular second messengers cAMP and $\mathrm{Ca}^{++}(35,36)$, have been found to acutely or chronically regulate tight junctionmediated paracellular permeability. The finding that cytochalasin D, a drug which destabilizes filamentous actin, caused prompt increases in paracellular permeability, led to the hy- 
Table II. Effect of Insulin on Other Epithelial Cell Lines

\begin{tabular}{|c|c|c|c|c|c|}
\hline \multirow[b]{2}{*}{ Cell line } & \multirow[b]{2}{*}{ Origin } & \multicolumn{2}{|c|}{ Resistance } & \multirow[b]{2}{*}{$(n)$} & \multirow[b]{2}{*}{$P$} \\
\hline & & Control & Insulin & & \\
\hline & \multicolumn{5}{|c|}{$\Omega-\mathrm{cm}^{2}$} \\
\hline HCT-8 & $\begin{array}{l}\text { Human ileum- } \\
\text { cecum }\end{array}$ & $346 \pm 69$ & $72 \pm 49$ & (8) & $<0.0001$ \\
\hline $\mathrm{CaCO}_{2}$ & Human colon & $253 \pm 74$ & $105 \pm 39$ & (5) & $<0.005$ \\
\hline MDCK & Dog kidney & $952 \pm 103$ & $785 \pm 337$ & (5) & NS \\
\hline LLC-PK 1 & Pig kidney & $94 \pm 13$ & $88 \pm 15$ & (8) & NS \\
\hline
\end{tabular}

Replicate monolayers of each cell line were grown on permeable supports for 7-14 $d$ until stable resistances were obtained. Half the monolayers were treated with $3 \mu \mathrm{g} / \mathrm{ml}$ purified bovine insulin for $4 \mathrm{~d}$ at which time both the control and the insulin treated monolayers were mounted in Ussing chambers for resistance measurements. Values are the mean \pm SD for $n$ monolayers. Student's unpaired $t$ test was used to compare the results. Insulin had no effect on the basal $I_{\mathrm{sc}}$ in any of the cell lines tested.

pothesis that the tensile forces within the peri-junctional actin ring control tight junction structure and function (26-28). The present report supports this hypothesis. Chronic exposure to insulin caused thinning and focal condensation of the perijunctional actin ring. These changes in cytoskeletal structure were subtle compared to the effects of cytochalasin or $C$. difficile toxin A $(20,27)$, but remarkably similar to those induced by interferon- $\gamma(21)$.

Insulin was shown to be effective only when added to the serosal side of established monolayers, strongly suggesting that insulin is mediating its effect on the paracellular pathway through a receptor localized in the basolateral membrane. The $\mathrm{ED}_{50}$ for insulin in decreasing transepithelial resistance was found to be $3.9 \mathrm{ng} / \mathrm{ml}(0.68 \mathrm{nM})$. This value is in the upper physiologic range of insulin and similar to the $K_{d}$ of the highaffinity insulin binding site of isolated mouse intestinal epithelial cells (37). However, the $\mathrm{ED}_{50}$ 's for insulin's effects on increasing $\mathrm{Na}^{+}$and mannitol fluxes were much higher and paralleled that found for the effect on conductance $(\sim 63 \mathrm{ng} / \mathrm{ml}$, $\sim 11 \mathrm{nM})$. The large difference between the $\mathrm{ED}_{50}$ values for decreased resistance and increased conductance is due to the reciprocal relationship between these two parameters and to the apparent negative cooperativity which tends to exaggerate the reciprocal relationship. It is well known that insulin at superphysiological doses can bind to the type I IGF receptor (11). The apparent $K_{d}$ for this interaction in most tissues is $>150 \mathrm{nM}$ which is considerably higher than the concentration of insulin found to half-maximally increase conductance. Furthermore, insulin has been reported to be relatively unstable in DME: Ham's F12 media (38), which could result in an underestimate of the potency for insulin's effect on transepithelial resistance and conductance. These arguments tend to rule out type I IGF receptor mediation of insulin's effect on T84 cells. However, in preliminary studies, we have found human recombinant IGFs I and II cause an increase in the paracellular permeability of T84 cell monolayers (39). Since we have yet to determine the nature and affinity of the insulin and IGF receptors in T84 cells or the degree of peptide degradation during culture, it is currently impossible to absolutely ascribe the effect of insulin to interaction with its own receptor. The available evidence strongly suggests that insulin is acting through its own receptor.
An indirect effect of insulin caused by induction and secretion of an autocrine factor seems unlikely since daily media changes had no effect on insulin-induced decline in resistance. Furthermore, insulin did not appear to be acting to potentiate the effect of another factor in the serum since it still caused a pronounced decline in the resistance of monolayers maintained under serum-free conditions. Insulin produced only a few of the biological responses in T84 cells that have been found in other tissues. At confluent densities, in the presence of serum supplement, insulin did not stimulate cell division. Insulin did appear to stimulate glucose utilization and protein synthesis and the effect of insulin on paracellular permeability was found to require protein synthesis. Cycloheximide; at a concentration sufficient to inhibit protein synthesis by $75 \%$ while still allowing monolayers to retain their functional integrity, blocked the insulin-induced decline in resistance. Inhibition of the insulin's effect on resistance by cycloheximide could be due to inhibition of receptor recycling after down-regulation of the insulin receptor. While this possibility cannot be rigorously excluded, the paradoxical observation that the combination of insulin and cycloheximide caused a significant increase in resistance suggests that insulin receptors are still functionally present. This observation also suggests that insulin can mediate an opposing effect on paracellular permeability by a process which does not require protein synthesis.

The possibility of a physiological role for insulin in regulating the junctional permeability of epithelial cells must be tempered by the limited scope of our observations. Insulin was found to decrease the transepithelial resistance across monolayers produced by two other carcinoma-derived intestinal epithelial cell lines, but not across those produced by two "normal" kidney-derived cell lines. From these observations, it is difficult to conclude whether the effect of insulin on paracellular permeability is a response uniquely associated with intestinal epithelia or with well-differentiated carcinomas. However, insulin in combination with aldosterone has been reported to increase the paracellular permeability of the A6 toad kidney cell line (17). Thus, regulation of paracellular permeability by insulin may be a general phenomenon applicable to a specific type or subset of epithelial cells.

The potential physiologic importance of insulin in regulation of paracellular permeability must also be tempered by the requirement for chronic ( $>2 \mathrm{~d}$ ) exposure. Since serum insulin normally fluctuates rapidly according to the nutritional status of the individual, it is unlikely in vivo that epithelial cells would be exposed chronically to elevated levels of insulin. In this respect insulin-like growth factors, which are maintained at relatively constant levels in the blood and can be produced in locally high concentrations (10), are more likely in vivo to mediate such changes in paracellular permeability. Since several recent reports have linked elevated IGF levels with chronic inflammatory conditions $(40,41)$, they could play an important role in increased mucosal permeability associated with these conditions. We are currently investigating the nature and role of IGFs and IGF receptors in mediating increased epithelial paracellular permeability.

\section{Acknowledgments}

We thank Dr. Calvin Olsen for use of his flourescent microscope and Drs. Eli Ipp and Hsu Fang Chu for radioimmunoassay of insulin.

This study was supported by grant 3P30 DK-36200 from the National Institute of Diabetes and Digestive Diseases. Hoon Kang was 
supported by the Harbor-UCLA Collegium Summer Fellowship Program.

\section{References}

1. Murakami, H., and H. Masui. 1980. Hormonal control of human colon carcinoma cell growth in serum-free media. Proc. Natl. Acad. Sci. USA. 77:3464-3468.

2. Madara, J. L., J. Stafford, K. Dharmsathaphorn, and S. Carlson. 1987. Structural analysis of a human intestinal epithelial cell line. Gastroenterology. 92:1133-1145.

3. Madara, J. L., and K. Dharmsathaphorn. 1985. Occluding junction structure-function relationships in a cultured epithelial monolayer. J. Cell Biol. 101:2124-2133.

4. Dharmsathaphorn, K., K. G. Mandel, J. A. McRoberts, L. D. Tisdale, and H. Masui. 1984. A human colonic tumor cell line that maintains vectorial electrolyte transport. Am. J. Physiol. 246:G204G208.

5. Dharmsathaphorn, K., K. G. Mandel, H. Masui, and J. A. McRoberts. 1985. VIP-induced chloride secretion by a human colonic epithelial cell line: direct participation of a basolaterally localized $\mathrm{Na}^{+}$, $\mathrm{K}^{+}, \mathrm{Cl}^{-}$cotransport system. J. Clin. Invest. 75:462-471.

6. McRoberts, J. A., and K. E. Barrett. 1989. Hormone regulated ion transport in T84 human colonic cells. In Functional Epithelial Cells in Culture. K. S. Matlin, and J. D. Valentich, editors. Alan R. Liss, Inc., New York. 235-265.

7. Welsh, M., P. Smith, P. Fromm, and R. Frizzell. 1982. Crypts are the site of intestinal fluid and electrolyte secretion. Science (Wash. DC). 218:1219-1221.

8. Shafrir, E., M. Bergman, and P. Felig. 1987. The endocrine pancreas: diabetes mellitus. In Endrocrinology and Metabolism. P. Felig, J. D. Baxter, A. E. Broadus, and L. A. Frohman, editors. McGraw-Hill Book Co., Inc., New York. 1043-1206.

9. Barnes, D., and G. Sato. 1980. Serum-free cell culture: a unifying approach. Cell. 22:649-655.

10. Froesch, E. R., C. Schmid, J. Schwander, and J. Zapf. 1985. Actions of insulin-like growth factors. Annu. Rev. Physiol. 47:443-467.

11. Rechler, M. 1985. The nature and regulation of the receptors for insulin-like growth factors. Annu. Rev. Physiol. 47:425-442.

12. Steele-Perkins, G., J. Turner, J. C. Edman, J. Hari, S. B. Pierce, C. Stover, W. J. Rutter, and R. A. Roth. 1988. Expression and characterization of a functional human insulin-like growth factor I receptor. J. Biol. Chem. 263:11486-11492.

13. Bar, R. S., M. Boes, B. L. Dake, B. A. Booth, S. A. Henley, and A. Sander. 1988. Insulin, insulin-like growth factors and vascular endothelium. Am. J. Med. 85:59-70.

14. Prosser, C. G., L. Sankaran, L. Hennighausen, and Y. J. Topper. 1987. Comparison of the roles of insulin and insulin-like growth factor $I$ in casein gene expression and the development of $\alpha$-lactalbumin and glucose transport activities in the mouse mammary epithelial cell line. Endocrinology. 120:1411-1416.

15. Flier, J. S., P. Usher, and A. L. Moses. 1986. Monoclonal antibody to type I insulin-like growth factor (IGF-I) receptor blocks IGF-I receptor mediated DNA synthesis: clarification of the mitogenic mechanisms of IGF-I and insulin in human skin fibroblasts. Proc. Natl. Acad. Sci. USA. 83:664-668.

16. Verspohl, E. J., R. A. Roth, R. Vigneri, and I. R. Goldfine. 1984. Dual regulation of glycogen metabolism by insulin and insulinlike growth factors in human heptoma cells (HEP-G2). J. Clin. Invest. 74:1436-1443.

17. Fidelman, M. L., and C. O. Watlington. 1987. Effect of aldosterone and insulin on mannitol, $\mathrm{Na}^{+}$and $\mathrm{Cl}^{-}$fluxes in cultured epithelia of renal origin (A6): evidence for increased permeability in the paracellular pathway. Biochim. Biophys. Acta. 931:205-214.

18. Madara, J. L. 1988. Tight junction dynamics: is paracellular transport regulated? Cell. 53:497-498.

19. Mullin, J. M., and T. O. O'Brien. 1986. Effects of tumor promoters on LLC-PK1 renal epithelial tight junctions and transepithelial fluxes. Am. J. Physiol. 251:C597-C602.
20. Hecht, G., C. Pothoulakis, J. T. LaMont, and J. L. Madara. 1988. Clostridium difficile toxin A perturbs cytoskeletal structure and tight junction permeability of cultured human intestinal epithelial monolayers. J. Clin. Invest. 82:1516-1524.

21. Madara, J. L., and J. Stafford. 1989. Interferon- $\gamma$ directly affects barrier function of cultured intestinal epithelial monolayer. $J$. Clin. Invest. 83:724-727.

22. Rochat, T., J. Casale, G. W. Hunninghake, and M. W. Peterson. 1988. Neutrophil cathepsin $G$ increases permeability of cultured type II pneumocytes. Am. J. Physiol. 255:C603-C611.

23. Hill, B. T., and S. Whatley. 1975. A simple rapid microassay for DNA. FEBS (Fed. Eur. Biochem. Soc.) Lett. 56:20-23.

24. Barrett, K. E., P. A. Huott, S. S. Shah, K. Dharmsathaphorn, and S. I. Wasserman. 1989. Differing effects of apical and basolateral adenosine on colonic epithelial cell line T84. Am. J. Physiol. 256:C197-C203.

25. Dawson, D. C. 1977. $\mathrm{Na}$ and $\mathrm{Cl}$ transport across the isolated turtle colon: parallel pathways for transmural ion. J. Membr. Biol. 37:213-233.

26. Madara, J. L., D. Barenberg, and S. Carlson. 1986. Effects of cytochalasin $\mathrm{D}$ on occluding junctions of intestinal absorptive cells: further evidence that the cytoskeleton may influence junctional permeability and junctional charge selectivity. J. Cell Biol. 102:21252136.

27. Madara, J. L., J. Stafford, D. Barenberg, and S. Carlson. 1988. Functional coupling of tight junctions and microfilaments in T84 monolayers. Am. J. Physiol. 254:G416-G423.

28. Madara, J. L., R. Moore, and S. Carlson. 1987. Alteration of tight junction structure and permeability by cytoskeletal contraction. Am. J. Physiol. 253:C854-C861.

29. Shasby, D. M., M. Winter, and S. S. Shasby. 1988. Oxidants and conductance of culture epithelial cell monolayers: inositol phospholipid hydrolysis. Am. J. Physiol. 255:C781-C788.

30. Defronzo, R. A., C. R. Cooke, R. Andres, G. R. Faloona, and P. J. Davis. 1975. The effect of insulin on renal handling of sodium potassium calcium and phosphate in man. J. Clin. Invest. 55:845-855.

31. Cox, M., and I. Singer. 1977. Insulin-mediated $\mathrm{Na}^{+}$transport in the toad urinary bladder. Am. J. Physiol. 232:F270-F277.

32. Crabbé, J. 1981. Stimulation by insulin of transepithelial sodium transport. Ann. NY Acad. Sci. 372:220-271.

33. Civan, M. M., K. Peterson-Yantorno, and T. G. O'Brien. 1988. Insulin and phorbol ester stimulate conductive $\mathrm{Na}^{+}$transport through a common pathway. Proc. Natl. Acad. Sci. USA. 85:963-967.

34. Fidelman, M. L., J. M. May, T. U. L. Biber, and C. O. Watlington. 1982. Insulin stimulation of $\mathrm{Na}^{+}$transport and glucose metabolism in cultured kidney cells. Am. J. Physiol. 242:C121-C123.

35. Duffey, M. E., B. Hainau, S. Ho, and C. J. Bentzel. 1981. Regulation of epithelial tight junction permeability by cyclic AMP. Nature (Lond.). 294:451-453.

36. Palant, C. E., M. E. Duffey, B. K. Mookerjee, S. Ho, and C. J. Bentzel. 1983. $\mathrm{Ca}^{2+}$ regulation of tight-junction permeability and structure in Necturas gallbladder. Am. J. Physiol. 245:C203-C212.

37. Gallo-Payet, N., and J. S. Hugon. 1984. Insulin receptors in isolated adult mouse intestinal cells: studies in vivo and in organ culture. Endrocrinology. 114:1885-1892.

38. Mather, J. P., and G. H. Sato. 1979. The growth of mouse melanoma cells in hormone-supplemented medium. Exp. Cell Res. 120:191-200.

39. McRoberts, J. A., R. Aranda, N. Riley, and H. Kang. 1989. Insulin and insulin-like growth factors regulate the paracellular permeability of T84 human colonic epithelial cells. Gastroenterology. 96:A337. (Abstr.)

40. Petruson, B., H-A. Hansson, and K. Petruson. 1988. Insulinlike growth factor I is a possible pathogenic mechanism in nasal polyps. Acta Oto-Laryngol. 106:156-160.

41. Rom, W. N., P. Basset, G. A. Fells, T. Nukiwa, B. C. Trapnell, and R. G. Crystal. 1988. Alveolar macrophages release an insulin-like growth factor I-type molecule. J. Clin. Invest. 82:1685-1693. 